\title{
Drawing a distinction between false Gallicisms and adapted French borrowings in English
}

\author{
Ramón Martí Solano
}

\section{Introduction}

False borrowings, also known as pseudo-borrowings, are not easy to classify as their definition may vary significantly from one scholar to another. Here follows the definition of false borrowing by the French lexicologist Jean Tournier: "Il arrive exceptionnellement qu' un mot perçu comme un emprunt à une langue étrangère n'existe pas dans cette langue, ou existe sous une autre forme. On a alors affaire à un faux emprunt. Exemples : bon viveur, ${ }^{1}$ folie de grandeur. (Les mots français sont bon vivant, folie des grandeurs)." (Tournier 1991: 75) [Exceptionally a word that is perceived as being borrowed from another language may not actually exist in that language, or not in an identical form; such words can be considered pseudo-loanwords, e.g. bon viveur, folie de grandeur (the original French words being bon vivant, folie des grandeurs).]. ${ }^{2}$

Tournier's narrow definition of false borrowing is strictly applied to words which either do not exist in French (bon viveur) or have a slightly different form (folie de grandeur), which in the examples provided is a matter of derivational and inflectional morphology respectively. According to this definition, the classic examples of false Anglicisms in French, namely smoking 'dinner jacket', parking 'car park' or footing 'jogging', would not fit in as all these words exist in the English language with exactly the same form. ${ }^{3}$ In any case, no occurrences of bon viveur or of folie de grandeur have been found in the Corpus of Contemporary American English (COCA). The former is an undisputed Briticism whereas the latter has its native counterpart in the phrase delusions of grandeur which is found 71 times in the COCA.

When investigating false borrowings one cannot skirt round the notion of the different levels of mastery of the orthographical and grammatical intricacies of a foreign language. It is obvious that the existence of the 'right' and the 'wrong' forms of a French word in a dictionary entry (bon vivant and bon viveur respectively) can be interpreted as clear evidence of both groups of speakers. The Cambridge Advanced Learner's Dictionary (CALD) registers bon vivant but also supplies bon viveur between brackets with the label also UK. It is my intention to distinguish the whole range of phenomena regarding adapted French loanwords in English as well as setting them against false Gallicisms.

The words analysed in this study are but a sample of French borrowings and false Gallicisms in English. Words have been searched for and selected manually in the American Heritage Dictionary $(A H D)$ and in three dictionaries of foreign words and phrases (Ayto 1995; Bliss 1966; Speake 1998). I have also carried out a search by wildcarts in the British National Corpus $(B N C), C O C A$ and in the CD-ROM version of the CALD. In order to detect potential French borrowings, the following wildcart combinations were used: *age, *ante, *eau, *erie, *esse, *et, *ette, *eur, *euse, *ier, *ière, *our.

\footnotetext{
${ }^{1}$ This seems to be one of the most clear-cut and classic examples of false Gallicisms. As Ayto (1991: xii) puts it: "Nor does English stop at reinterpreting the pronunciation of foreign words. Sometimes it even invents new 'foreign' words. The best-known is the pseudo-French bon viveur."

${ }^{2}$ I would like to thank Dr Hélène Chuquet for the translation of this quotation.

${ }^{3}$ Parking and footing are mentioned as "pseudo-loans" by Humbley (2002: 121-122). Thogmartin (1984: 452) classifies parking, footing and smoking as "pseudo-borrowing ending in -ing". Otman (1989: 121) describes parking and smoking as productions françaises à partir de ce suffixe [-ing] [French products made from that suffix [-ing]].
} 


\section{A definition of false Gallicism}

When compared with false Anglicisms, false Gallicisms seem to conform to a slightly different type of classification. The three fundamental types of false Anglicisms in Italian, namely autonomous compounds, compound ellipsis and semantic shifts (Furiassi 2006: 274) cannot be exactly applied to false Gallicisms. As a matter of fact, I have not found any instances of false Gallicisms that could be assigned to the first group in which are included false Anglicisms such as Fr. tennisman 'tennis player' or It. autostop 'hitch-hiking' (Furiassi 2010: 141). Conversely, I have found some instances of the second category and a plentiful supply of false Gallicims for the third category.

As a starting point I will consider one of the classic examples of supposedly false Gallicisms in English, i.e. rendezvous. To the tutored eye the first minor, though noticeable, difference is typographical - the word is hyphenated in French whereas in English it is a solid compound. ${ }^{4}$ So far it could be argued that the English word does not exist in French as no such fluctuation in form is allowed in this language (the word is always hyphenated as it retains the spelling of the second person plural of the imperative mood of the pronominal verb se rendre 'to go to', from which it derives). The second and much more striking feature is the conversion process of this noun in English, thus becoming a verb that once inflected produces forms such as rendezvoused or rendezvousing. Conversely, the semantic narrowing (a secret meeting place for lovers) and the metonymic shift (the word designating a place or a venue) are common both in French and in English and it is precisely these features of semantic specialization that have traditionally been put forward as the main arguments for the classification of this type of loanwords as false borrowings. It is consequently a matter of the utmost importance to verify both in authoritative lexicographic sources and in large general corpora all the possible senses of a word in the donor language (DL) so as not to act with precipitation over these issues. Hence, rendezvous will be classified as a genuine French loanword because no typographical or orthographical adaptations, conversion and subsequent native inflection, and semantic narrowing in the recipient language (RL) will count as valid criteria for the labelling of French borrowings as false Gallicisms.

In what follows I will be using a much broader definition of false borrowings than that advanced by Tournier (1991: 75) in order to include not only the formal component but also the semantic one. So, partially following and adapting the definition of pseudo-Anglicisms by Sørensen (1997: 18) - but also in agreement with Furiassi's (2003: 123) and Fischer's (2008: 7) standpoint on false Anglicisms - false Gallicisms will be defined as words that look French, but which deviate from genuine French words either morphologically, lexically or semantically.

The approach to false Gallicisms is totally different depending on whether these are examined from a diachronic or a synchronic perspective. When looking at the English word courier ("a person who carries important messages or documents for someone else") one can notice that this is both an adapted French loan (the corresponding French word is courrier, with a double $r$ ) and a semantic false Gallicism as the meaning of the English word courier is conveyed in contemporary French by the word coursier. ${ }^{5}$ On the other hand, and from a diachronic point of view, English adopted the French word in the early $18^{\text {th }}$ century ${ }^{6}$ with the regular spelling at that time, so it could be said that the English word corresponds exactly to the French one. Besides, and from a semantic perspective, the word courrier is also used in

\footnotetext{
${ }^{4}$ A search in the $B N C$ has yielded the following results: 262 tokens of rendezvous against 10 of rendez-vous. The $C A L D$ only registers the unhyphenated form.

${ }^{5}$ See Appendix A for a list of false Gallicisms, their definition in English and translation into French.

${ }^{6}$ The first recorded example in the Oxford English Dictionary (OED) of the word courier with the spelling courrier is from 1718.
} 
French to designate a courier, especially in compounds such as courrier d'ambassade or courrier diplomatique whose equivalent in English is diplomatic courier.

Finally, a distinction should be drawn between false Gallicisms and false friends. These two concepts are occasionally mixed as false friends can sometimes become a sort of catch-all category that encompasses everything from cognates, false friends and false loanwords. For instance, Kirk-Green (1995: 193) categorises venue as a false friend when this loanword should be analysed as a false Gallicism since the meaning of the word is English is different from the meaning of the exact same word in French. ${ }^{7}$

\section{Formal adaptation of French borrowings}

The main mechanisms of formal adaptation of French loanwords and phrases will be outlined taking into consideration all possible typographical, diacritical, orthographical, morphological, lexical and semantic changes when benchmarked against the corresponding native forms in the French language.

The English word connoisseur (Fr. connaisseur) could exemplify the French loanword in English that has preserved an ancient spelling, currently obsolete in Modern French according to the Oxford English Dictionary $(O E D)$. However, the only ancient form of the word provided by the Dictionnaire historique de la langue française (DHLF) is connoiseor and not connoisseur. One could hypothesise that the unorthodox Old and Middle French ending -eor was changed to a more suitable and French-looking -eur in English. In any case this item will not be considered as a false Gallicism as, depending on the source, the word has either preserved a former foreign spelling or has been orthographically adapted in the RL.

\subsection{Typographical, diacritical and orthographical adaptations}

Words can be borrowed by a RL exactly as they are written in the DL but sometimes these borrowings can take a somewhat different form in the RL. These formal changes or adaptations are certainly the product of the assimilation and usage of the actual borrowing in the DL as speakers are more often than not unfamiliar with and unaware of the orthographical and grammatical rules applied to foreign loans. When the original French phrase de luxe is spelt as one word in English, i.e. deluxe (Otman 1989: 122), this simply reflects the linguistic unawareness of dealing with a combination of preposition and noun in French by Englishlanguage speakers. But most of the formal differences mainly concern the use of accents and other diacritics. A remarkable example of this lack of accentual rigour is the loan papier mâché. No tokens have been found in the $B N C$ of the original French spelling either with one or both diacritics. However, there are 16 tokens of this compound without diacritics in the $B N C$.

As regards spelling, one should differentiate between long-established adapted spelling, as is the case of maisonette ${ }^{8}$ (Fr. maisonnette) and lexicalised variants as with sobriquet/soubriquet (Fr. sobriquet) and ambience/ambiance (Fr. ambiance). These variant forms merely reflect the maintenance in contemporary English of a former spelling of the French word as explained by Ayto (1991: 288): "Defying chronology, English actually borrowed the word's original form soubriquet (now superseded in French), in the $19^{\text {th }}$ century, and this is now if anything commoner than sobriquet.". These examples are to be distinguished, in their turn, from the somewhat erratic orthography reflected in forms such as

\footnotetext{
${ }^{7}$ The En. loan venue is 'the place where a public event or meeting happens' whereas in French this same word simply means 'arrival or coming'.

${ }^{8}$ The $O E D$ adds the following commentary in the dictionary entry: "The correct spelling with - $n n$ - is rarely found."
} 
de rigeur instead of the correct de rigueur: the cluster of vowels is especially difficult to retain, which could partially explain the incorrect spelling. ${ }^{9}$ Portmanteau (Fr. portemanteau) and apartment (Fr. appartement) illustrate another spelling feature of formal adaptation of French loans into English. The elision of the vowel $e$ from the original French words reflects the level of phonological assimilation of the loans as well as the lexical association with such English words as port and apart.

As observed in the case of apartment, there seems to be a tendency of orthographical adaptation of French loans concerning double and single consonants. Some double consonants in the DL are reduced to one as in maisonette and courier whereas some single consonants in the DL are doubled in English as can be seen in such loans as pannier (Fr. panier) and fillet ${ }^{10}$ (Fr. filet).

\subsection{Morphological adaptations}

However, it is in morphology, and more precisely in inflection and affixation, where the most prominent examples abound. The epitome of English false French suffixation is arbitrageur, a derived noun from the specialised word arbitrage ${ }^{11}$. The corresponding French noun is arbitragiste and not arbitrageur. The latter is an English-derived word that looks entirely French but which does not exist as a word in this language, which automatically makes of this derivative a genuine false Gallicism.

Other instances of morphology are related to the use of the French inflectional endings for the plural and the feminine gender. The lexicalised French phrase the nouveau riche has as its counterpart the French les nouveaux riches in which all three constituents take the appropriate plural ending, $-s,-x$ and $-s$ respectively. Similarly the English adjective sauté as used, for instance, in sauté potatoes is, as all adjectives in English, invariable, whereas French has four different forms: the masculine singular sauté, the masculine plural sautés, the feminine singular sautée and the feminine plural sautées. The latter would be used to translate the example of sauté potatoes (Fr. pommes de terre sautées). It is worth remembering that correct inflected forms of French adjectives and nouns can sometimes be found in English texts, but this remains exceptional as these loans tend to be registered in dictionaries - and used in examples - in their invariable form, which clearly accounts for their level of integration in the morphological system of the English language.

A special formal case is represented by the widespread use in English of the feminine ending of a number of French nouns and adjectives used both for male and female referents. The classic example is blonde (the feminine form of blond in French) used also for men (Bliss 1966: 10). Other examples include the English words confidante, naïve and debutante as illustrated by the following example:

(1) Lord Falconer, who is also the lord chancellor and a close confidante of Tony Blair, said a move to proportional representation would mean politicians were preoccupied with establishing coalitions. (The Guardian 20 May 2005)

\footnotetext{
${ }^{9} 5$ tokens of the incorrect form against 40 of the correct form have been found in the $B N C$.

${ }^{10}$ Even though the $C A L D$ specifies that the form fillet is used in British English and the form filet in American English, we have found 455 tokens of filet and 621 tokens of fillet in the COCA, which contradicts the information supplied in the dictionary and evidences the vacillation over the spelling of French loans.

${ }^{11}$ Here is the definition of arbitrage included in the CALD: "the method on the stock exchange of buying something in one place and selling it in another place at the same time, in order to make a profit from the difference in price in the two places."
} 
The word in bold in (1) would be interpreted by a French speaker as having a female referent due to the inflectional ending - $e$. Endings notwithstanding, the referent in the English sentence is Lord Falconer, undoubtedly a man. Obviously the form confidant is generally found for a male referent, which makes of confidant(e) a typical example of masculine/feminine suffix fluctuation depending greatly on the grammatical competence of the speaker. Finally, the adjective naïve has supplanted the masculine French adjective naïf both in lexicographical entries and in texts. The non-correspondence between grammatical gender in French and actual forms in English does not constitute a criterion for classifying a given French loan as a false Gallicism.

As concerns pluralisation it is interesting to note the adaptation of some French loanwords to the English morphological pattern present in the lexical paradigm that includes words such as trousers, shorts, pants, knickers, dungarees, leggings, etc. This is exactly the case of the French loan fatigue whose origin is to be found in the French phrases habit de fatigue or vêtement de fatigue that are defined as réservé pour les tâches pénibles [especially worn when doing tough jobs] but which are not exclusively used in the field of soldiering, contrary to the English word fatigues.

(2) Asked recently what he would do when the war ended in Croatia, Arkan said he would sell his six captured tanks, hang up his combat fatigues and return to his ice cream parlour business in Belgrade. $(B N C)$

The French loan in bold in (2) constitutes then a false Gallicism as the word has been semantically reanalysed in English and is translated in French by treillis. The case of the English word culottes is rather complex as it involves several mechanisms, both formal and semantic. On the one hand, the corresponding French word is jupe-culotte, which makes of the English word an adaptation by compound ellipsis and pluralisation. On the other hand, there is a word in French, culottes, whose meaning does not coincide with its English counterpart as it is used in French to designate underpants or underwear in general.

\subsection{Conversion of nouns or adjectives into verbs}

Loanwords are subject to conversion or zero derivation as much as words from AngloSaxon origin. Finesse, valet, rendezvous, compere, sabotage, chauffeur, julienne, massage, sauté, début and many more other nouns and adjectives can be converted into verbs as illustrated in the following examples:

(3) She worked with Cyril Stapleton's BBC Showband and featured on the Goon Show. For a decade from the late 1970 s, she compered a highly successful BBC Radio 2 show. (The Guardian 29 May 2000)

(4) I have recently been through a bit of a root vegetable phase [...] thinly sliced or julienned, dressed with a tasty little vinaigrette and tossed with dried fruit or pulses or crisp winter leaves - or all of the above. (The Guardian 18 January 2012)

The conjugated forms in bold in (3) and (4) are to be regarded as native adaptations of the French loans and not as false Gallicisms. The same criterion should be applied to other fairly common French loans from the semantic field of food and cookery when they are used as verbs, for instance to fillet or to purée as there is no semantic change involved in the conversion process. 


\subsection{Lexical adaptations}

This section will be dealing with cases of compound ellipsis, by which one or more words in a compound or a noun phrase are elided and that is unquestionably one of the commonest mechanisms of creating pseudo-loans in many European languages (Alexieva 2002: 257; Busse \& Görlach 2002: 29; Graedler 2002: 77; Humbley 2002: 121; Maximova 2002: 208; Pulcini 2002: 163; Rodríguez González 2002: 147). Sometimes the elision is possible in the DL as it happens with Fr. tableau vivant, or simply Fr. tableau, whereas in other cases the elision in English, which is optional, is not possible in French if the same meaning is to be conveyed, as with coup d'état ${ }^{12}$ and haute couture. These loans can be used with exactly the same meaning in English in their abbreviated forms, coup and couture respectively, as shown in (5) and (6). It is only in their non-canonical, single-word form that these loans are considered as false Gallicisms.

(5) At first, he accepted military rule by Mr. Musharraf, who as head of the armed forces had seized power in a coup in 1999. (COCA)

(6) But if you want to understand why couture still matters, look inside a Valentino ballgown, a YSL Le Smoking, a Chanel suit. (COCA)

Contrary to the above examples, the loan séance, whose French counterpart is séance de spiritisme, is only found in English as a single word and as such it is attested in dictionary entries. ${ }^{13}$ Otman (1989: 119) analyses séance as an instance of semantic narrowing in the RL and puts it on a par with French loanwords such as ensemble or bouquet. I would rather look at it as a case of compound ellipsis and therefore as a false Gallicism.

One could think that it is always the head of the compound or the noun phrase that is retained as the shortened version in English. However, this is not always the case as other procedures may come into play. The English au pair is a shortened version of the original French noun phrase jeune fille au pair, literally 'young girl on equal terms', in which the elided constituent is precisely the head of the noun phrase. As my aim is to investigate the current state of affairs concerning false Gallicisms in English, this example will be considered as such and hence will be included in the list of false Gallicisms provided in Appendix A.

Thogmartin (1984: 454) mentions four cases of French pseudo-borrowings in English, namely brassiere, au gratin, au jus and à la mode. The use of the portmanteau morph au whose corresponding feminine form is à la - can be compared, although not in the same proportion, to the use of the -ing form in false Anglicisms. The morph is so characteristically French that it is made in English to precede French loans from the semantic field of food when these are masculine, as with gratin and jus. The result of this ill-assorted combination, to a French eye, becomes automatically a false Gallicism in English. For instance, the English phrase potatoes au gratin would be translated in French as gratin de pommes de terre. 5 tokens of au gratin have been found in the BNC and a total number of 53 in the COCA. Used mainly in combination with the word potatoes, the phrase can be placed both before and after the noun: potatoes au gratin or au gratin potatoes. But it can also be used as the head of a noun phrase, as in au gratin of potatoes and even as a single noun in itself which functions as

\footnotetext{
${ }^{12}$ Other compounds having as head the French word coup attested in the OED are coup de force, coup de foudre, coup de glotte, coup de grâce, coup de main, coup d'œil, coup de poing, coup de soleil, coup de théâtre and coup de vent. It goes without saying that only coup d'état does allow the elision of the complement of the noun head.

${ }^{13}$ We have checked this entry in a monolingual dictionary, the CALD, as well as in a bilingual dictionary, The Oxford-Hachette French Dictionary (OHFD).
} 
the subject of the sentence as in The au gratin + predicate. This is undeniably a false Gallicism - the actual combination au gratin simply does not exist in French.

Other word-relation processes can be observed, as for instance paronymy, which is certainly responsible for the existence of the English compound double entendre, a typical example of pseudo-Gallicism. There is a similar phrase in French à double entente, which means exactly the same although the sexual innuendo of the English phrase is not necessarily present in the French one. The two French words, entendre and entente, are etymologically related and phonologically close, which makes them paronymous. According to Renouf (2004: 533) "[t]he modern French semantic equivalent of double entendre is mot à double sens or mot en sous-entendu".

\section{Semantic false Gallicisms}

Different types of semantic mechanisms are underway in the lexical borrowing process in languages in contact and especially between French and English. These are extremely varied and can go from semantic extension or reduction and metonymic, metaphoric or meronymic shifts to connotational changes such as amelioration or pejoration. Two common examples are the English words chandelier and crayon which refer to slightly different objects than their French counterparts chandelier 'candlestick' and crayon 'pencil'. As Winford (2010: 175) points out, "many borrowings do not represent complete adoption of a foreign item with both its form and meaning" and this is especially true of semantic false Gallicisms.

There may even be non-native word creations such as papier mâché and nom de plume. ${ }^{14}$ The $O E D$ clearly specifies in a special note in the entry of papier mâché that "[a]lthough composed of French words, the name papier mâché appears not to be of French origin. It is not recognised in the French Dictionaries of the Académie, Littré or Hatz-Darm, except in its literal sense of "chewed paper'." I do not concur with the above statement since both nouns are attested in the Trésor de la langue française informatisé (TLFi). Moreover, the French general corpus Frantext registers its first appearance in 1736 (there are 111 tokens in Frantext where the noun is used to complement the head noun figure, visage or mine, the three of them meaning 'face') and its use as "pieces of paper mixed with glue or with flour and water and used to make decorative objects or models" (CALD) is clearly apparent in several examples such as the one in (7), from 1938:

(7) Laforgue ne retrouvait que des cheveux familiers, comme ces cheveux naturels plantés sur les masques chinois de papier mâché. (Frantext)

According to Ayto (1991: 211) nom de plume "gives every indication of being a French expression, but in fact it is quite uncommon in French, and it could well be that it was coined in English as a pseudo-Frenchism, perhaps modelled on the long-established nom de guerre (it is first recorded in the 1820s, in the works of Thomas de Quincey)." As regards papier mâché Ayto (1991: 225) adds that "[p]apier 'paper' and mâché 'chewed' are of course French words, but the term papier mâché appears to have been concocted in English in the mid- $18^{\text {th }}$ century: the usual French expression for what we call papier mâché is carton-pâte." If the synchronic criterion should be applied here, nom de plume and papier mâché are not to be considered as false Gallicisms as they are used in French in exactly the same sense as in English, irrespective of the fact that they were created in English.

\footnotetext{
${ }^{14}$ Only nom de plume is included in Görlach (2003: 146) and is described as pseudo-French.
} 
It should be noted as well that some words can be at the same time a genuine Gallicism and a false Gallicism: the word charade, when used in the plural, describes a sort of team game both in French and in English. However, the semantic extension that the word has developed in English is unknown in French. Example (8) shows the use of the English word charade for which the French translation would be comédie.

(8) The wounds Giles had inflicted were only just beginning to heal. Had she ever really meant anything to him? Or had all his compliments and charm, so convincing at the time, been just a charade to get him what he wanted? $(B N C)$

The same situation applies to the English word fracas as used in (9). In English the word is synonymous with 'brawl' or 'fight', whereas in French the word is associated with strong, unpleasant noise and could be translated as 'crash', 'din' or even 'roar'.

(9) In Tascosa he had encountered a brother of the dead Natchez gambler accompanied by two of the irate companions. He had killed two of his enemies and wounded the other, coming out of the fracas with a bullet in his leg. $(C O C A)$

A special use of the French prepositional phrase en suite - also spelt as a solid or as a hyphenated compound - has been developed in English to designate "a bathroom which is directly connected to a bedroom or a bedroom which is connected to a bathroom" (CALD). Although the phrase is mainly used as an adjective, an en suite bathroom, it can also be found as a noun. The loan is much more common and widespread in British English than in American English where it is primarily used to describe a type of compact bathroom in the specialized context of motor boating and yachting.

Negligee is sometimes given as an example of an English word creation (Ayto 1991: 206). However, the French word negligé designates, as well as déshabillé, "a woman's decorative dressing gown made of light material" $(C A L D)$. At times the search in the OxfordHachette French Dictionary $(O H F D)$ can bring about the most puzzling and indiscernible situation since Fr. négligé is translated as En. negligee whereas En. negligee is translated as Fr. déshabillé. Moreover, the existence of the English word dishabille (with a variant form deshabille $^{15}$ ) turns the whole issue into a sort of lexical mélange. Consequently, this loan will not be classified as a false Gallicism for the same reasons as papier mâché or nom de plume, namely that the word is used in contemporary French with exactly the same meaning although not the same form - as the English loan.

The English word cortege designates "a slowly moving line of people, or cars at a funeral" $(C A L D)$. This is a case of semantic restriction and of formal truncation from the original French cortège funèbre. The French cortège is not only used for various types of ceremonies, but also for demonstrations or to refer to groups of students or workers. Once more, the bilingual dictionary supplies contradictory information: the translation of Fr. cortège funèbre is En. cortege whereas the translation of En. cortege is Fr. cortège. Regarded fundamentally as a case of compound ellipsis, this loan will be categorised as a false Gallicism.

Finally, the English words exposé and dossier have been borrowed from French and have both undergone a semantic pejoration process. The corresponding French words are connotatively neutral whereas their English counterparts are usually associated with criminals or criminal acts and contexts. Connotational processes such as pejoration or amelioration will

\footnotetext{
${ }^{15}$ This information is taken from the $A H D$ that defines dishabille as "the state of being partially or very casually dressed; a state of undress" and as "casual or lounging attire".
} 
not be regarded as valid semantic mechanisms to label French loans as false Gallicisms as they represent a special type of semantic narrowing - in the cases above there are no morphological, lexical or semantic differences and both words are translated into French by their homonyms.

\section{False Gallicisms and English language varieties}

Some false Gallicisms are not of general use in English but are restricted to a certain geographical area. In what follows in particular several instances of false Gallicisms that are either Briticisms or Americanisms will be examined. Furthermore, some false Gallicisms can be classified according not to regional varieties but to different types of technical or specialised languages.

\subsection{Briticisms}

Words or phrases that are especially used in Great Britain are known as Briticisms. Well-known Briticisms are flat (apartment), bloke (guy) or central reservation (median strip), to mention just a few. The English Gallicism cagoule is labelled UK in the CALD and means "a light jacket with a hood which protects the wearer against wet and windy weather" 16 as illustrated in (10):

(10) If you can imagine being on a steep, snow-covered slope, below which there is a $1000 \mathrm{~m}(3,500 \mathrm{ft})$ sheer drop, would you prefer to be wearing a shiny nylon cagoule or a rough old woollen jumper? $(B N C)$

The French word cagoule has historically been used to designate a cowl, i.e. "a large loose covering for the head and sometimes shoulders, but not the face, which is worn especially by monks" (CALD). In modern times the word has taken on a second sense in French and corresponds to the English word balaclava.

The word bonnet can either mean a type of hat or, exclusively in British English, "the metal cover over the part of the car where the engine is" $(C A L D)$. It is in this sense that the word bonnet is to be considered as a false Anglicism - the corresponding French word is capot - and as a Briticism since the equivalent word in American English is hood.

Courier in English has the general meaning of "a person who carries important messages or documents for someone else" $(C A L D)$ and is quasi-synonymous with messenger. However, this loanword has taken on a specialised meaning in British English in the field of tourism as "a person who looks after a group of people on holiday especially by giving them advice on what to do, what to see, etc" $(C A L D)$.

\subsection{Americanisms}

\footnotetext{
${ }^{16}$ Something which corroborates the fact that cagoule is a Briticism is that no entry of this word has been found in the lexicon of the Webster's Third New International Dictionary (WTNID). However, the derivative cagoulard ("a member of a secret reactionary revolutionary French organization suppressed in 1937-38") is included as this refers to a historically relevant figure in French history, which is obviously beyond any varietal distinction.
} 
Words or phrases that are associated with the variety of the English language spoken in the United States are known as Americanisms. Well-known Americanisms include cookie (biscuit), rooster (cock) or scallion (spring onion) among many others.

Valet is a clearly identifiable French loan which is phonologically marked as the final $t$ is silent, thus imitating the original French pronunciation. This word which is currently used to designate "someone in a hotel who cleans clothes" (CALD) has taken on a special meaning in American English and is applied to refer to "someone at a hotel or restaurant that puts your car in a parking space for you" $(C A L D)$ as shown in (11):

(11) The paparazzi were busy snapping photos of the solo Olsen twin as she waited for the valet to fetch her car. (COCA)

It is well established that a great number of French words and phrases related to food and wine have made their way into English and many other languages worldwide. However, some of these loans have taken on a special sense in British or American English, as is the case with hors d'oeuvres. ${ }^{17}$ Another rather conspicuous false Gallicism in American English is entrée which in this language variety means main course as illustrated in (12).

(12) The cooks are given offbeat ingredients and just 20-30 minutes to make an appetizer, entree and dessert, resulting in such offerings as sea urchin French toast. $(C O C A)$

A very well-known example of semantic shift is represented by the French loan bureau and the sense that the word has taken on in American English. A bureau in Great Britain is a writing desk whereas in the United States the word is used to refer to a chest of drawers, ${ }^{18}$ as shown in (13).

(13) Helen walked to a bureau and searched the drawers, one filled with scarves and nylons, the next with panties neatly folded and separated by color. (COCA)

Foyer is another case of a false Gallicism exclusively in the sense that this word has developed in American English as "the room in a house or apartment leading from the front door to other rooms, where things like coats and hats are kept" $(C A L D)$. The loan is synonymous with hall or hallway as illustrated in (14):

(14) The main entrance leads to a small foyer, beyond which is a spacious living room with original hardwood floors, a wood-burning stove and glass doors that open to a back patio and bathe the space in natural light. (COCA)

So far I have dealt with words that are common to both language varieties but which have developed a special and distinct sense in American English. This is simply part of a larger linguistic phenomenon which is common and well-attested in the different varieties of the four main European languages spoken in the American continent, i.e. English, Spanish, Portuguese and French. On the contrary, there are French loans that are only found in

\footnotetext{
${ }^{17}$ Hors d'oeuvres means "a small savoury dish eaten at the start of a meal" in British English whereas in American English it means "small pieces of food eaten at a party" (CALD).

${ }^{18}$ Not only in American English does this French loan acquire a new sense. The Swedish formally-adapted French loan byrå (Fr. bureau) has exactly the same meaning as its American counterpart, which automatically makes of it a false Gallicism in Swedish.
} 
American English, and that is precisely the case of pompadour (15), a word that designates a type of hairdo that the British call quiff and the French call banane.

(15) The other was younger, maybe a couple years older than I was. He was brownhaired; he had a big pompadour and he combed his hair back into a duck's ass, a popular style at the time. (COCA)

$A u$ jus seems to be in use only in American English as 16 tokens of the phrase have been found in the COCA and none in the BNC. The phrase has an entry in the WTNID and is defined as "served in the meat juice obtained from roasting (roast beef au jus)". In order to express the same idea French would need a more complex structure to translate the example provided at the end of the definition, but in any case the combination of the portmanteau morph $a u$ and the noun jus does not make any sense in French.

Finally, the phrase à la mode represents another instance of an American false Gallicism since it is used to designate a scoop of vanilla ice-cream accompanying a dessert as shown in (16):

(16) I've long been amused by diners who choose a dessert like apple pie a la mode, at about 600 calories a serving, and sprinkle artificial sweetener in their coffee or tea to replace the 16 calories in a teaspoon of sugar. (COCA)

\subsection{Technical or specialised languages}

The very few examples of false Gallicisms in this section are representative of a certain type of borrowings that have made their way into terminology or are restricted to a specialised area or technical field. It is a well-known fact that English has borrowed an important number of French words and phrases along centuries of mutual lexical contact and that cookery, fashion, law and the military have been particularly receptive to French lexis. As a general rule, the large majority of French loans in these and other specialised areas have retained their original sense in English although some particular terms related to traditional trades or artisan professional activities could be catalogued in the list of false Gallicisms.

In the specialised field of the leather industry I have found the French-looking word, surcingle. The $A H D$ defines it as "[a] girth that binds a saddle, pack, or blanket to the body of a horse". The word as such does not exist in French which uses the terms surfaix or sousventrière to refer to the same object. The English word is etymologically and semantically related to contemporary French sangle, which has exactly the same meaning but which is nonspecialised and therefore makes part of the French core vocabulary, contrary to the word surcingle in English, completely unknown to the non-specialists.

In the technical language of sewing or needlework, mention should be made of the English term appliqué, whose French translation is application. The word appliqué means "[a] decoration or ornament, as in needlework, made by cutting pieces of one material and applying them to the surface of another" $(A H D)$, and clearly constitutes a case of technical false Gallicism as the French word applique 'applied' is the past participle of the verb appliquer 'to apply' and is used exclusively as an adjective in combinations such as linguistique appliquée 'applied linguistics' or mathématiques appliqués 'applied mathematics'.

Lastly, I would like to point out the use of the French loan rosette in architecture to designate "a circular ornament, carved, painted or moulded resembling a formalised rose" $(G D T)$. The equivalent specialised term in French is rosace. 


\section{Conclusion}

It is essential to subscribe to a synchronic or to a diachronic perspective in the analysis of false borrowings in general, and of false Gallicisms in English in particular: borrowings such as nom de plume and papier mâché have exactly the same meaning in contemporary French and in contemporary English, regardless of the fact that, according to highly reputable sources, they were not coined in France. A sharp distinction should also be drawn between genuine Gallicisms that have been adapted orthographically and remain formally stable in contemporary English (maisonette) or that fluctuate as far as gender and plural agreement is concerned (confidant/e, the nouveau/x riche/s) and false Gallicisms which either do not exist as such in French (arbitrageur) or have been truncated or clipped (couture) or if they do, they have a completely different semantic referent (chandelier). As with native Anglo-Saxon words, some French loanwords do not necessarily mean the same thing on both shores of the Atlantic (bureau) and some others may have acquired a specific meaning in a certain technical or specialised language (appliqué).

Other studies of false Gallicisms (and of false borrowings in general) would be necessary so as to contrast items, analyses and results that will eventually pave the way for the publication of a dictionary of false borrowings in English.

\section{References}

Alexieva, Nevena. 2002. Bulgarian. In Manfred Görlach (ed.), English in Europe, 241-260. Oxford: Oxford University Press.

[AHD] The American Heritage Dictionary. 1982. Boston: Houghton Mifflin.

Ayto, John. 1991. Dictionary of Foreign Words in English. Edinburgh: Wordsworth Reference.

Bliss, Alan J. 1966. A Dictionary of Foreign Words and Phrases in Current English. London: Routledge and Kegan Paul.

[BNC] The British National Corpus. http://corpus.byu.edu/bnc/x.asp?w=1024\&h=640 (accessed 14 June 2013).

Busse, Ulrich \& Manfred Görlach. 2002. German. In Manfred Görlach (ed.), English in Europe, 13-36. Oxford: Oxford University Press.

[CALD] The Cambridge Advanced Learner's Dictionary. 2008. Cambridge: Cambridge University Press.

[COCA] The Corpus of Contemporary American English. http://corpus.byu.edu/coca/x.asp?w=1024\&h=640 (accessed 14 June 2013).

[DHLF] Dictionnaire historique de la langue française. 2000. Paris: Le Robert.

Fischer, Roswitha. 2008. Introduction: Studying Anglicisms. In Roswitha Fischer \& Hanna Pułaczewska (eds.), Anglicisms in Europe: Linguistic Diversity in a Global Context, 1-14. Newcastle-upon-Tyne: Cambridge Scholars Publishing.

Frantext. http://www.frantext.fr/ (accessed 5 June 2013).

Furiassi, Cristiano. 2003. False Anglicisms in Italian Monolingual Dictionaries: A Case Study of Some Electronic Editions. International Journal of Lexicography XVI(2). 121-142.

Furiassi, Cristiano. 2006. The Making of a Dictionary of False Anglicisms in Italian. In Elisa Corino, Carla Marello \& Cristina Onesti (eds.), Proceedings of the $12^{\text {th }}$ EURALEX International Congress, Torino, $6^{\text {th }}-9^{\text {th }}$ September 2006, vol. I, 273-280. Alessandria: Edizioni dell' Orso.

Furiassi, Cristiano. 2010. False Anglicisms in Italian. Monza: Polimetrica. 
Görlach, Manfred. 2003. English Words Abroad. Amsterdam \& Philadelphia: John Benjamins.

Graedler, Anne-Line. 2002. Norwegian. In Manfred Görlach (ed.), English in Europe, 57-81. Oxford: Oxford University Press.

[GDT] Le Grand Dictionnaire Terminologique, http://gdt.oqlf.gouv.qc.ca/index.aspx (accessed 14 June 2013).

Humbley, John. 2002. French. In Manfred Görlach (ed.), English in Europe, 108-127. Oxford: Oxford University Press.

Kirk-Green, C.W.E. 1995. NTC's Dictionary of Faux Amis. Lincolnwood, IL: National Textbook Company.

Maximova, Tamara. 2002. Russian. In Manfred Görlach (ed.), English in Europe, 195-212. Oxford: Oxford University Press.

Otman, Gabriel. 1989. En français dans le texte: étude des emprunts français an angloamérican. The French Review 63(1). 111-126.

[OED] The Oxford English Dictionary. 1989. Oxford: Clarendon Press.

[OHFD] The Oxford-Hachette French Dictionary. 2007. Oxford: Oxford University Press.

Pulcini, Virginia. 2002. Italian. In Manfred Görlach (ed.), English in Europe, 151-167. Oxford: Oxford University Press.

Renouf, Antoinette. 2004. Shall we hors d'oeuvres? The assimilation of Gallicisms into English. In Christian Leclère, Éric Laporte, Mireille Piot \& Max Silberztein (eds.), Lexique, Syntaxe et Lexique-Grammaire/Syntax, Lexis \& Lexicon-Grammar. Papers in honour of Maurice Gross, 527-545. Amsterdam \& Philadelphia: John Benjamins.

Rodríguez González, Félix. 2002. Spanish. In Manfred Görlach (ed.), English in Europe, 128-150. Oxford: Oxford University Press.

Sørensen, Knud. 1997. A Dictionary of Anglicisms in Danish. Copenhagen: Munksgaard.

Speake, Jennifer. 1998. The Oxford Dictionary of Foreign Words and Phrases. Oxford: Oxford University Press.

The Guardian. http://www.guardian.co.uk/ (accessed 5 June 2013).

Thogmartin, Clyde. 1984. Some "English" words in French. The French Review 57(4). 447-455.

Tournier, Jean. 1991. Structures lexicales de l'anglais. Paris: Nathan.

[TLFi] Le Trésor de la Langue Française informatisé. http://atilf.atilf.fr/tlf.htm (accessed 14 June 2013).

[WTNID] Webster's Third New International Dictionary. 1961. Chicago: Merriam Webster.

Winford, Donald. 2010. Contact and Borrowing. In Raymond Hickey (ed.), The Handbook of Language Contact, 170-187. Oxford: Wiley-Blackwell.

\section{Appendix A}

The following table lists in the first column the words analysed as false Gallicisms and in the second column, their definition as found in the CALD. Finally, the third column provides the translation into French given by the $O H F D$. It should be noted that when a given item does not have an entry in either of the two dictionaries mentioned above, other monolingual lexicographic sources have been consulted, namely The American Heritage Dictionary (AHD), Le Grand Dictionnaire Terminologique (GDT) and the Webster's Third New International Dictionary (WTNID). False Gallicisms specific to the American variety are labelled $U S$ and those mainly used in the British Isles are labelled $U K$. 


\begin{tabular}{|c|c|c|}
\hline Gallicism & $(C A L D)$ & French $(O H F D)$ \\
\hline à la mode $(U S)$ & Served with ice cream. & $\begin{array}{l}\text { avec une glace à la } \\
\text { vanille }\end{array}$ \\
\hline appliqué & $\begin{array}{l}\text { Decorative work in which one piece of cloth is } \\
\text { sewn or fixed onto another, or the activity of } \\
\text { decorating cloth in this way. }\end{array}$ & application \\
\hline au gratin & $\begin{array}{l}\text { Cooked with a covering of cheese or small } \\
\text { pieces of bread mixed with butter. }\end{array}$ & gratin \\
\hline au jus $(U S)$ & $\begin{array}{l}\text { Served in the meat juice obtained from roasting. } \\
\text { (WTNID) }\end{array}$ & $\begin{array}{l}\text { servi dans le jus de } \\
\text { cuisson }\end{array}$ \\
\hline au pair & $\begin{array}{l}\text { A foreign person, usually a young woman, who } \\
\text { lives with a family in order to learn their } \\
\text { language and who looks after the children or } \\
\text { cleans the house in return for meals, a room and } \\
\text { a small payment. }\end{array}$ & jeune fille au pair \\
\hline arbitrageur & A person who makes money from arbitrage. & arbitragiste \\
\hline bonnet $(U K)$ & $\begin{array}{l}\text { The metal cover over the part of a car where the } \\
\text { engine is. }\end{array}$ & capot \\
\hline bon viveur $(U K)$ & $\begin{array}{l}\text { A person who enjoys good food and wines and } \\
\text { likes going to restaurants and parties. }\end{array}$ & bon vivant \\
\hline brassiere & $\begin{array}{l}\text { A piece of women's underwear that supports } \\
\text { the breasts. }\end{array}$ & soutien-gorge \\
\hline bureau $(U S)$ & $\begin{array}{l}\text { A piece of furniture with drawers in which you } \\
\text { keep things such as clothes. }\end{array}$ & commode \\
\hline cagoule $(U K)$ & $\begin{array}{l}\text { A light jacket with a hood which protects the } \\
\text { wearer against wet and windy weather. }\end{array}$ & anorak, $K-W a y \AA$ \\
\hline chandelier & $\begin{array}{l}\text { A decorative light which hangs from the ceiling } \\
\text { and has several parts like branches for holding } \\
\text { bulbs or, especially in the past, candles. }\end{array}$ & lustre \\
\hline charade & An act or event which is clearly false. & comédie \\
\hline cortege & $\begin{array}{l}\text { A slowly moving line of people, or cars at a } \\
\text { funeral. }\end{array}$ & cortège funèbre \\
\hline coup (d'état) & $\begin{array}{l}\text { Sudden illegal, often violent, taking of } \\
\text { government power, especially by (part of) an } \\
\text { army. }\end{array}$ & coup d'État \\
\hline courier & $\begin{array}{l}\text { A person who carries important messages or } \\
\text { documents for someone else. }\end{array}$ & coursier \\
\hline courier $(U K)$ & $\begin{array}{l}\text { Person who looks after a group of people on } \\
\text { holiday especially by giving them advice on } \\
\text { what to do, what to see, etc. }\end{array}$ & guide \\
\hline crayon & $\begin{array}{l}\text { A small stick of coloured wax used for drawing } \\
\text { or writing. }\end{array}$ & craie grasse \\
\hline culottes & Women's short trousers which look like a skirt. & jupe-culotte \\
\hline double entendre & $\begin{array}{l}\text { A word or phrase that might be understood in } \\
\text { two ways, one of which is usually sexual. }\end{array}$ & $\begin{array}{l}\text { sous-entendu } \\
\text { (grivois) }\end{array}$ \\
\hline $\begin{array}{l}\text { en suite, en-suite, } \\
\text { ensuite }\end{array}$ & $\begin{array}{l}\text { Describes a bathroom which is directly } \\
\text { connected to a bedroom or a bedroom which is } \\
\text { connected to a bathroom. }\end{array}$ & $\begin{array}{l}\text { salle de } \\
\text { attenante }\end{array}$ \\
\hline
\end{tabular}




\begin{tabular}{|c|c|c|}
\hline entrée $(U S)$ & The main dish of a meal. & plat principal \\
\hline fatigues & $\begin{array}{l}\text { A loose brownish green uniform worn by } \\
\text { soldiers. }\end{array}$ & treillis \\
\hline $\begin{array}{l}\text { folie } \\
\text { grandeur }\end{array}$ & Delusions of grandeur & folie des grandeurs \\
\hline foyer $(U S)$ & $\begin{array}{l}\text { The room in a house or apartment leading from } \\
\text { the front door to other rooms, where things like } \\
\text { coats and hats are kept. }\end{array}$ & entrée \\
\hline fracas & A noisy argument or fight. & $\begin{array}{l}\text { altercation, } \\
\text { accrochage }\end{array}$ \\
\hline (haute) couture & $\begin{array}{l}\text { The designing, making and selling of expensive } \\
\text { fashionable clothing, or the clothes themselves. }\end{array}$ & haute couture \\
\hline pannier & $\begin{array}{l}\text { A bag or similar container, especially one of a } \\
\text { pair that hangs on either side of a bicycle, } \\
\text { motorcycle, or animal such as a horse or } \\
\text { donkey. }\end{array}$ & sacoche \\
\hline pompadour $(U S)$ & $\begin{array}{l}\text { A hairstyle, worn usually by men, in which the } \\
\text { hair at the front of the head is brushed up. }\end{array}$ & banane \\
\hline résumé (US) & $\begin{array}{l}\text { A short written description of your education, } \\
\text { qualifications, previous jobs and sometimes } \\
\text { also your personal interests, which you send to } \\
\text { an employer when you are trying to get a job. }\end{array}$ & $\begin{array}{l}C V, \\
\text { (vitae) }\end{array}$ \\
\hline rosette & $\begin{array}{l}\text { A circular ornament, carved, painted or } \\
\text { moulded resembling a formalised rose; also a } \\
\text { rose-shaped patera. }(G D T)\end{array}$ & rosace $(G D T)$ \\
\hline surcingle & $\begin{array}{l}\text { A girth that binds a saddle, pack, or blanket to } \\
\text { the body of a horse. }(A H D)\end{array}$ & $\begin{array}{l}\text { Surfaix, } \quad \text { sous- } \\
\text { ventrière }(G D T)\end{array}$ \\
\hline valet $(U S)$ & $\begin{array}{l}\text { Someone at a hotel or restaurant who puts your } \\
\text { car in a parking space for you. }\end{array}$ & voiturier \\
\hline venue & $\begin{array}{l}\text { The place where a public event or meeting } \\
\text { happens. }\end{array}$ & lieu \\
\hline
\end{tabular}

\footnotetext{
${ }^{19}$ No definitions or translations have been found in the $C A L D$ and in the $O H F D$. However, the phrase is attested in Ayto's Dictionaries of Foreign Words and Phrases.
} 